\title{
Adenoid cystic carcinoma of Bartholin's gland diagnosed after lung lobectomy: Review of the literature and a case presentation
}

\section{Segmental akciğer lobektomi sonrast rastlanan adenoid kistik Bartholin kanseri: Literatür değerlendirilmesi ve olgu takdimi}

\author{
(1) Seda Şahin Aker1, (1) Cevriye Cansız Ersöz², (1) Furat Ortaç1 \\ ${ }_{1}^{1}$ Ankara University Faculty of Medicine, Department of Gynecologic Oncology, Ankara, Turkey \\ ${ }^{2}$ Ankara University Faculty of Medicine, Department of Pathology, Ankara, Turkey
}

\begin{abstract}
Bartholin's gland was first identified in human female in 1675 by Caspar Bartholin. The Bartholin gland is composed of several epithelial types: The body is mucinous acini, the duct is predominantly transitional epithelium, and the orifice is the squamous epithelium. Primary carcinoma of the bartholin's gland is an uncommon neoplasm. Adenoid cystic carcinoma (ACC) of bartholin gland carcinom is a rare variant of bartholin gland carcinoma, comprising $15 \%$ of all bartholin gland malignancies. ACC of the Bartholin's gland is characterized by slow growth so recurrence and distant metastases can take a long period. So distant metastasis has been found in only a few cases to the lungs, liver, bone and brain. Here, we present the case of Bartholin's gland ACC after four years follow up and presented with a lung metastasis.
\end{abstract}

Keywords: Adenoid cystic carcinoma of the Bartholin's gland, vulvar cancer, Bartholin gland carsinom

$\ddot{\mathrm{O} z}$

Bartholin bezi 1675 yılında Caspar Bartholin tarafından kadın genital anatomisinde tanımlanmıştır. Bartholin bezi çeşitli epitel tipleri ile kaplıdır; gövdesi müsinöz, kanal transisyonel ve orifis skuamöz epitelle kaplıdır. Primer bartholin kanseri nadir görülmektedir. Bartholin gland kanserinin adenoid kistik karsinom ise çok nadir görülmekte ve bartholin kanserlerin \% 15'ini oluşturmaktadır. Literatürde adenoid kistik karsinomlu 90'dan az hasta tariflenmektedir ve yavaş büyüme paterni nedeniyle rekürrens ve uzak metastaz uzun vakit alabilmektedir. Dolayısıyla akciğere, karaciğere ve kemiğe uzak metastaz çok az hastada rastlanmaktadır. Biz 4 yıllık hastalıksız takip sonrası akciğer lobektomisinde saptanan adenoid kistik bartholin kanseri olgusunu sunmaktayız. Anahtar Kelimeler: Adenoid kistik Bartholin karsinomu, vulvar kanser, Bartholin bezi karsinomu

\section{Introduction}

The Bartholin gland was first identified in the human female body in 1675 by Caspar Bartholin ${ }^{(1)}$. The main function of the Bartholin gland is to secrete mucus to provide vaginal and vulvar lubrication. Each Bartholin gland is approximately $0.5 \mathrm{~cm}$ in size and drains mucous into a duct $2.5 \mathrm{~cm}$ long. The ducts open onto the vulvar vestibule at the four and eight o'clock positions on each side of the vaginal orifice. The Bartholin gland has different epithelial types: the body is mucinous acini, the duct is transitional epithelium, and the orifice is squamous epithelium ${ }^{(2)}$. Primary carcinoma of the Bartholin gland is an uncommon neoplasm. Bartholin gland carcinoma (BGC) comprises approximately 0.1 to $5 \%$ of all vulvar carcinomas and $<1 \%$ of female genital malignancies ${ }^{(3)}$. BGC has many histologic types: adenocarcinoma, squamous, adenosquamous, transitional cell carcinoma, and adenoid cystic carcinoma (ACC) $)^{(4)}$. Adenocarcinomas and squamous cell carcinomas each account for approximately $40 \%$ and adenosquamous carcinomas account for approximately $5 \%$ of $B G C s^{(5)}$. ACC of BGC is a rare variant, comprising $15 \%$ of all Bartholin gland malignancies and the first documentation of ACC was identified by Klobin in $1864^{(6)}$. In the literature, fewer than 90 patients have been described. ACC of the Bartholin gland is characterized by slow growth, so recurrence and distant

Address for Correspondence/Yazışma Adresi: Seda Şahin Aker MD,

Ankara University Faculty of Medicine, Department of Gynecologic Oncology, Ankara, Turkey

Phone: +90 5446926538 E-mail: drsedasahinaker@hotmail.com ORCID ID: orcid.org/0000-0001-6192-5726

Received/Geliș Tarihi: 12.03.2020 Accepted/Kabul Tarihi: 18.07.2020

${ }^{\oplus}$ Copyright 2020 by Turkish Society of Obstetrics and Gynecology

Turkish Journal of Obstetrics and Gynecology published by Galenos Publishing House 
metastases can take a long period. Only in rare cases are distant metastasis seen in the lungs, liver, bone, and brain. We present a case of ACC in a woman who presented with lung metastasis after four years of follow-up.

\section{Case Presentation}

In September 2014, a 58-year-old gravidity 5 parity 2 menopausal women presented with a palpable mass and vulval pain of the left Bartholin's gland area. Under general anesthesia, the left Bartholin's gland was excised with a Bartholin gland cyst prediagnosis. A pathologic examination revealed an ACC of the Bartholin gland, the tumor continued at the positive edge of surgery with negative perineural invasion. The unexpected malignant lesion was diagnosed and a scientific study was conducted for metastatic disease. Chest, abdomen, and pelvis computed tomography (CT) scans showed no metastatic disease. Then the patient underwent hemivulvectomy with left inguinofemoral lymph node dissection. After surgery, the pathology result showed a tumor on one side of the surgical margin and positive perineural invasion. The inguinofemoral lymph nodes were collected, all of which were tumor-free. The patient received no adjuvant treatment. We followed up the patient regularly and who showed no recurrence over a 4-year period. Forty-nine months after the surgery, she had chest pain and cough symptoms. A thorax CT scan was performed, which showed a right upper lung lesion in diameter of $1.2 * 1.1$ $\mathrm{cm}$ (Figure 1). In September 2018, the patient underwent a left pulmonary wedge resection. The diagnosis was clarified with pathologic results. It showed a lung metastasis of ACC with no tumor in lymph nodes and margins are negative (Figure 2). A pathology examination showed columns of cells arranged concentrically around gland-like spaces filled with eosinophilic periodic acid-Schiff-positive material. In addition, the examination showed the characteristic tumor proliferation in a cribriform pattern composed of nests, hence, the presence of ACC metastasis. Two years earlier, when the first ACC was diagnosed, it showed similar speciality and was clarified with immunohistochemical characteristics. Tumour cells were widely positive with SMA, CD117, and p63, and focally positive with CK7 and calponin (Figure 3). The patient is now diseasefree with 56 months of follow-up and stable disease.

\section{Discussion}

In 1864, Klob was the first to describe BGC. It has various types such as adenocarcinoma, squamous, adenosquamous, transitional cell carcinoma, and ACC. Ten to fifteen percent of patients have ACC, which is histologically similar to adenocarcinoma of the salivary glands ${ }^{(7)}$. ACC of the Bartholin gland is extremely rare. Only 80 cases have been reported in the literature ${ }^{(8)}$. Common symptoms are a painless mass, pruritus, dyspareunia, burning sensation, vulvar pain, and abnormal bleeding. Initial misdiagnosis or delayed diagnosis may occur in up to $50 \%$ of patients, with incorrect diagnoses of Bartholin cysts or abscesses ${ }^{(7)}$. The most frequent symptoms is a progressive enlargement or swelling in the vulva; the patients often experience pain, which is probably due to tumor involvement of nerves ${ }^{(9)}$. In our case, the patient was misdiagnosed as having a Bartholin cyst and underwent Bartholin gland excision. The patient underwent reexcision and inguinofemoral lymphadenectomy because of incomplete surgery and margins with the tumor. The Bartholin gland was excised for the primary treatment. In women aged over 40 years diagnosed with Bartholin cysts, fine needle aspiration cytology is to exclude malignancy recommended ${ }^{(10)}$. The incidence of Bartholin gland tumors is highest among women in their 60s. The incidence of BGC in one series was 0.023 per 100,000 woman-years in premenopausal women and 0.114 per 100,000 woman-years in postmenopausal women ${ }^{(11)}$; however, ACC of the Bartholin gland shows a different age predisposition. ACC can be shown from the late $20 s^{(8)}$. ACC of the Bartholin's gland

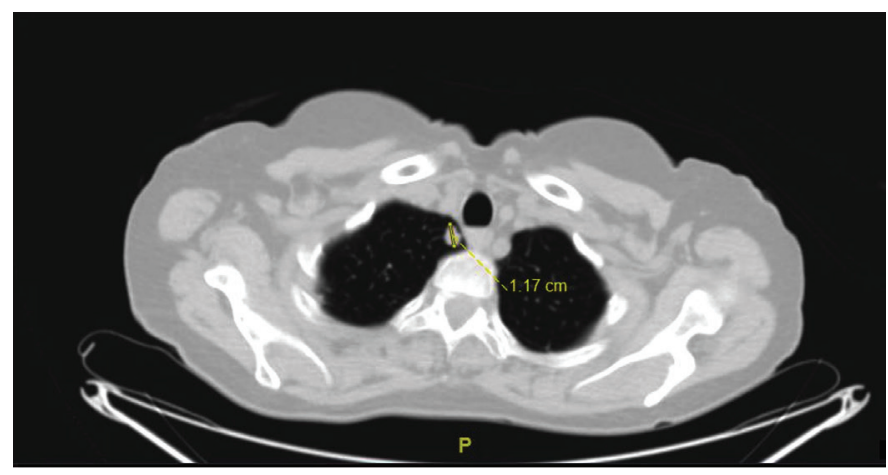

Figure 1. CT scan showed right upper lung lesion in diameter of $1,2 * 1,2 \mathrm{~cm}$

CT: Computed tomography

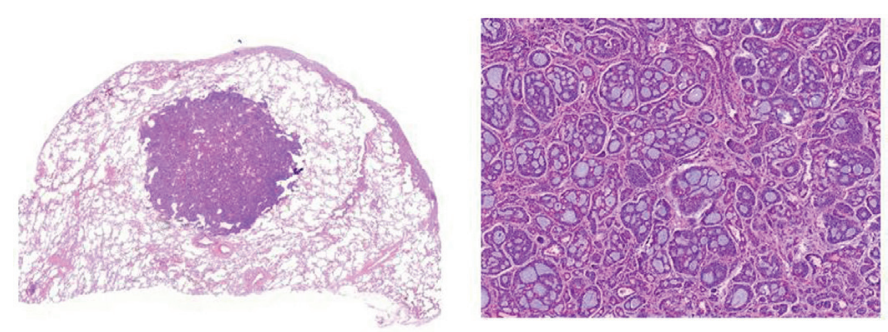

Tumor in peripheral lung paranchyma. H.Ex60 \& H.Ex100

Figure 2. Tumor in peripheral lung paranchyma
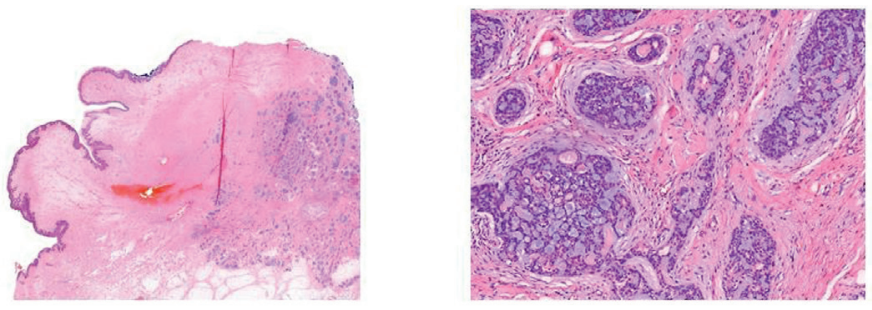

The tumor is composed of basaloid cells arranged in cribriform, tubular and solid growth patterns. Vulvectomy material. H.Ex60 \& H.Ex120

Figure 3. Tumor in vulvectomy material 
shares classic histologic features with ACC of the salivary gland. The tumor is composed of uniform, small cells arranged in cords and nests with a cribriform pattern, variable-sized cysts filled with an amphophilic or eosinophilic acellular basement membrane-like material. The tumor must be located in an appropriate anatomic location. Most tumors have perineural invasion, which is thought to contribute to its high local recurrence rate ${ }^{(12)}$. ACC of the Bartholin gland is characterized by slow growth, local recurrence, and distant metastases by intravascular spread may occur over a long period ${ }^{(13)}$. Distant metastasis of ACC is not common, it is very rare in the lung, brain, liver, and bone. Alsan et al..$^{(8)}$ showed the most prevalent distant metastasis of ACC site was lungs, followed by liver, and rarely bone. Our patient had a distant metastasis after 4 years of follow-up.

Optimal surgical treatment for ACC of the Bartholin gland is not identified with guidelines. Radical vulvectomy \pm inguinal lymphadenectomy and simple excision can both be performed. The most important point is to achieve a tumor-free margin. Yang et al. ${ }^{(14)}$ showed $68.9 \%$ of patients who had a simple excision had recurrence rate. Patients who underwent radical vulvectomy had a $42.9 \%$ recurrence rate; resection margins in the radical vulvectomy group were positive in $30 \%$ of the patients. The positive margin rate was $48 \%$ in the simple excision group. Hsu et al. ${ }^{(15)}$ presented two ACCs of Bartholin gland origin with lung metastasis; the first patient had a positive margin in pathologic examination and received postoperative adjuvant external beam radiotherapy, and distant metastasis (lung and bone) was found 42 months after the radiotherapy. The other patient who had tumor-free margins, had no adjuvant treatment. Fiftynine months after the surgery she had lung metastases. Yoon et al. ${ }^{(16)}$ presented 5 cases of ACC of the Bartholin gland. Two had lung metastases. In the first case, a 54-year-old woman had right-side radical local excision + ipsilateral inguinal lymph node dissection + adjuvan radiotherapy. Resection margins and perineural invasion were positive. She had lung metastasis twice 7 and 8 months later and underwent metastasectomy with subsequent chemotherapy (paclitaxel and carboplatin) for the first metastasis and metastasectomy only for the second metastasis. After 71 months' follow-up, she had stable disease. The second case was a 60-year-old woman who had left-side radical local excision and no adjuvant therapy. Resection margins and perineural invasion were positive. Local pelvic recurrence and distal metastases (lung) occurred in the patient, the local metastasis was removed. Lung metastases occurred 71.18 and 189 months after surgery and complete excision of the pulmonary lesion was not possible because of the number and size of the lesions. The patient had local excision and no adjuvant therapy. Resection margins and perineural invasion were positive. Local pelvic recurrence and distal metastases (lung) occurred in the patient, the local metastasis was removed. Lung metastases were at 71,179 and 189 months after surgery and complete excision of pulmonary lesion was not possible because the number and the size of lesions did not rise up. After 224 months' follow-up she had progressive disease ${ }^{(16)}$. In our case, like Yoon et al. ${ }^{(16)}$ cases, the patient had positive margins in pathologic examination, received no adjuvant treatment; she had lung metastases 49 months after surgery, and after 56 months follow-up, she has stable disease. When the distant metastasis was evaluated, it seemed to be related to margin positivity and perineural invasion. ACC of Bartholin's gland is a slow-growing tumor, long-term survival is excellent according to Copeland et al. ${ }^{(17)}$ The 5-year progress-free interval is $47 \%$ and the 5 -year survival rate is $71 \%$. They are $38 \%$ and $50 \%$, respectively, at 10 years, and $13 \%$ and $51 \%$ at 15 years. According to these results, it has been suggested to use 10- to 15-year-survival rates rather than 5-year survival rates for ACC of the Bartholin's gland. The patient of BG-ACC metastasis of Inguinal lymph node take place seldomly. However, if it occurs, it is ipsilateral to the primary tumor. In our case, there was no lymph node metastasis. In the literature, the effect of lymphadenectomy on survival and prognosis is controversial. There is little information on the treatment of metastasis and the management depends on the location. In literature, there are no data to support chemotherapy to prevent distant metastasis. If a distant metastasis exists, chemotherapy treatment alternatives such as chlorambucil-adriamycin, methotrexate-dactinomycin, cyclophosphamide-adriamycin-cisplatin or cyclophosphamide can be used $^{(14)}$. Various treatment modalities, including radiotherapy, may produce tumor regression. Publications have emphasized poor outcomes in patients with positive tumor margins even when treated with radiotherapy ${ }^{(18)}$. A prospective randomized study can provide the most powerful evidence for deciding the optimal treatment. Due to the rarity of ACC of the Bartolin gland, we can obtain data from reviews and large series. ACC of Bartholin's gland is a rare, vulvar malignancy with unpredictable biologic behavior. Physicians have to suspect it in women aged over 40 years with persistent Bartholin's gland masses. There is no consensus on the treatment and the treatment modality must be tailored according to each patient. Radical local excision or radical vulvectomy \pm lymphadenectomy seems to be the most suitable treatment. Positive surgical margins are a very important factor related to recurrence. Surgery, radiotherapy or chemotherapy regimens can be used for recurrence. Follow-up of ACC of the Bartholin gland has to be for a long period due its slow growth behavior.

\section{Ethics}

Peer-review: Externally peer-reviewed.

\section{Authorship Contributions}

Surgical and Medical Practices: F.O., Concept: S.S.A., C.C.Ö., Design: S.S.A., Data Collection or Processing: S.S.A., Analysis or Interpretation: S.Ş.A., Literature Search: S.Ş.A., Writing: S.Ş.A. Conflict of Interest: No conflict of interest was declared by the authors. 
Financial Disclosure: The authors declared that this study received no financial support

\section{References}

1. Chamlian DL, Taylor HB. Primary carcinoma of Bartholin's gland. A report of 24 patients. Obstet Gynecol 1972;39:489e94.

2. Heller DS, Bean S. Lesions of the Bartholin gland: a review. J Low Genit Tract Dis 2014;18:351.

3. National Cancer Institute. Cancer Stat Facts: Vulvar Cancer. https:// seer.cancer.gov/statfacts/html/vulva.html (Accessed on April 28, 2017).

4. Dunn S. Adenoid cystic carcinoma of Bartholin's gland - a review of the literature and report of a patient. Acta Obstet Gynecol Scand 1995;74:78-80.

5. Crum CP, McCluggage WG, Herrington CS, Regauer S, Wilkinson EJ. Tumours of the Vulva: Epithelial tumors. In: Kurman RJ, Carcangiu ML, Herrington CS, Young RH, editors. WHO Classification of Tumours of Female Reproductive Organs. Lyon: International Agency for Research on Cancer; 2014.p.237-8.

6. López-Varela E, Oliva E, McIntyre JF, Fuller AF. Primary treatment of Bar-tholin's gland carcinoma with radiation and chemoradiation: a report onten consecutive cases. Int J Gynecol Cancer 2007;17:6617.

7. Klob JM. Pathologische Anatomie der Weiblichen Sexualorgane Wein, 1864.

8. Alsan CI, Vinh-Hung V, Eren F, Abacioglu U. Adenoid cystic carcinoma of the Bartholin's gland: case report and systematic review of the literature. Eur J Gynaecol Oncol 2011;32:567-72.
9. Milchgrub S, Wiley EL, Vuitch F, Albores-Saavedra J. The tubular variant of adenoid cystic carcinoma of the Bartholin's gland. Am J Clin Pathol 1994;101:204-8.

10. Frable WJ, Goplerud DR. Adenoid cystic carcinoma of Bartholin's gland diagnosis by aspiration biopsy. Acta Cytol 1975;19:152-3.

11. Visco AG, Del Priore G. Postmenopausal bartholin gland enlargement: a hospital-based cancer risk assessment. Obstet Gynecol 1996;87:286-90.

12. Di Donato V, Casorelli A, Bardhi E, Vena F, Marchetti C, Muzii L, et al. Bartholin gland cancer. Crit Rev Oncol Hematol 2017;117:1-11.

13. Nasu K, Kawano Y, Takai N, Kashima K, Miyakawa I. Adenoid Cystic Carcinoma of Bartholin's Gland. Gynecol Obstet Invest 2005;59:54-8

14. Yang SY, Lee JW, Kim WS, Jung KL, Lee SJ, Lee JH, et al. Adenoid cystic carcinoma of the Bartholin's gland: report of two cases and review of the literatüre Gynecol Oncol 2006;100:422-5.

15. Hsu ST, Wang RC, Lu CH, Ke YM, Chen YT, Chou MM, et al. Report of two cases of adenoid cystic carcinoma of Bartholin's gland and review of literature. Taiwan J Obstet Gynecol 2013;52:113-6.

16. Yoon G, Kim HS, Lee YY, Kim TJ, Choi CH, Song SY, et al. Analysis of clinical outcomes of patients with adenoid cystic carcinoma of Bartholin glands. Int J Clin Exp Pathol 2015;8:5688-94.

17. Copeland LJ, Sneige N, Gershenson DM, Saul PB, AllenStringer C, Seskl JC. Adenoid cystic carcinoma of bartholingland. Obstet Gynecol 1986;67:115-20.

18. Smith LC, Lane N, Rankkow RM. Cylindroma (adenoid cystic carcinoma). Am J Surg 1965;110:519-26. 